\title{
Reflections on Violence: Three Theses
}

\author{
John Carroll
}

Published online: 19 January 2012

(C) Springer Science+Business Media, LLC 2012

\section{Violent Power is Exhilarating}

I well remember as a boy standing 1 day on the beach at Beaumaris, a beachside suburb of Melbourne, as U.S. fighter jets flew low overhead. First, there was a hum somewhere over the horizon, but nothing visible; then black specs approaching at lightning speed from across the bay, as if skimming the water. I ducked wide-eyed as they flashed overhead, gone in a second in which I had just time to take in the huge silver steel bodies, like monster supernatural birds, just above my head. I quivered with awe at the size, the deep thunder of the engines and the supersonic echo, the speed, and the sheer colossal poise of their flight. This was sublime power.

I also well remember the 1993 Australian football Grand Final. It wasn't a close match, as my team won easily. One of the moments that stands out, looking back, was when the hard-man on my side, Dean Wallis - characterised by brute physicality rather than style - hurtled at opposition backman Mil Hanna, launched himself into the air and hit him squarely with hip to shoulder, and shoulder to head. Hanna shook like a rag doll with the impact, then in slow motion seemed to go ricocheting sideways. A sudden hush descended over the 90,000 fans. Hanna hit the ground with a reverberating thud, like a felled tree. I remember being awestruck, exhilarated - with a sliver of bad conscience checking any outward sign of excitement. This was a moment of unscrupulous thuggery, and there was a trace of sadistic triumph in my reaction, flushed with the power of my team, and with little thought for either the unconscious player spread-eagled on the

J. Carroll $(\bowtie)$

Department of Sociology, La Trobe University,

Melbourne 3086, Australia

e-mail: J.Carroll@latrobe.edu.au turf, or the bad sportsmanship. Football's appeal has a lot to do with the identification with powerful, fast-moving men in hot pursuit of violent action; spiced by the frisson of alternating good and bad conscience.

The bad conscience that stalks around the issue of violence means that this is territory in which those who essay are prone to hypocrisy, self-deceit, and humanitarian fancy - of the kind that protests that humans are basically nice, and that it is only malevolent influences external to their own good natures that drive them to do harm to others.

In search of where the truth may lie, the best clues as to the temper of an era, and especially as to its darker sides, are often to be found in its leading works of art. In my view, the most insightful Western works of recent decades have all been produced by American television-notably the three series, The Sopranos, Deadwood, and Mad Men. It is striking that violence plays a major role in both of the first two productions.

In The Sopranos, the ordinary members of society are fascinated by life in the New Jersey Mafia gang, and especially that of its leader, Tony Soprano. Whenever Tony's own psychoanalyst, Dr Melfi, meets other analysts, whether socially or professionally, they eagerly probe the nature and doings of her patient. She herself can, at times, barely control her own voyeuristic titillation.

The culture of counselling is one of therapy and care, mediated by the relentless, unflappable calm of the analysts as they politely massage human nightmare, for hour after carefully-minuted hour. In this television series, it gives way to a near pornographic leering at a man who respects no rules, who has brute power, and who will, without a blink, exercise it. Tony Soprano moves in the world; he makes an impact; and he knows the blood-red pleasure of inflicting pain, of torturing, of breaking bones, and even of murdering 
formerly close and loyal friends. The ultra-civilised analysts are helplessly attracted to raw unscrupulous violence, like heroin addicts to a syringe.

It was not different for Socrates. In his last days before drinking poison, he had a dream that he was going home to Phthia. Phthia was not his home- - he had spent almost all of his 70 years in Athens. Phthia was the home of Achilles - the great heroic, man-slaughtering warrior brute, and the most effectively violent man to inhabit the classical Greek imagination. Socrates, by contrast, was the philosopher who dedicated his life to self-examination, and living the moral life; the forerunner of the psychoanalytic axiom that it is possible, through thinking, to reform character. Socrates, in his dream, is renouncing his vocation. Within the shadow of imminent death, his unconscious wish is to transform himself into the warrior hero.

Homer's Iliad is helpful to this discussion: it presents a distinction between three faces of violence. There is, firstly, exhilaration, exemplified by the Greek warrior, Diomedes. The early battle scenes are lyrical, as when Diomedes

.....went storming up the plain like a winter-swollen river in spate that scatters the dikes in its running current, one that the strong-compacted dikes can contain no longer, neither the mounded banks of the blossoming vineyards hold it rising suddenly as Zeus' rain makes heavy the water and many lovely works of the young men crumble beneath it.

Like these the massed battalions of the Trojans were scattered by Tydeus' son, and many as they were could not stand against him. ${ }^{1}$

The second face of violence in the Iliad is stark, unsentimental realism:

Idomeneus stabbed Erymas in the mouth with the pitiless bronze, so that the brazen spearhead smashed its way clean through below the brain in an upward stroke, and the white bones splintered, and the teeth were shaken out with the stroke and both eyes filled up with blood, and gaping he blew a spray of blood through the nostrils and through his mouth, and death in a dark mist closed in about him. $^{2}$

The clinical literalism belies a grim, sober, clear-eyed honesty —advising the listeners to shed their pretty illusions,

\footnotetext{
${ }^{1}$ Homer, Iliad, trans. Richmond Lattimore, University of Chicago Press, Chicago, 1951, book 5, lines 87-94.

${ }^{2}$ Iliad, book 16, lines 345-350.
}

gulp if they need to, nod, and get on with their business, for this is how it is.

The third face of violence in the Iliad is horror. When Achilles finally enters the fighting what follows is not glorious combat, but rampant one-sided slaughter. He is far too superior to any other warrior, a man "with no sweetness in his heart', rampaging at will through the Trojans, 'his invincible hands spattered with bloody filth'. When a young Trojan caught by Achilles sinks to his knees pleading for mercy, the great hero tells him he is of little consequence - for even he, the huge and splendid Achilles, will die soon. Achilles hacks the young Trojan across the neck, picks the body up by the foot and flings it, as if it were a piece of dead kelp, into the river, then 'spoke winged words of vaulting derision over him? ${ }^{3}$

\section{Violence Does Evil}

The human story is littered with examples. At the extreme, there are cases of psychopathic violence. I intend to bracket them out here, assuming they belong to a separate order, outside the human norm.

To clarify the distinction let me list some cases of violent psychopaths. In 1986 in Sydney, four men one night randomly abducted a 26-year-old-woman, Anita Cobby, from the side of the street, then spent an hourand-a-half repeatedly raping and bashing her, before slitting her throat. They showed no remorse at the trial. ${ }^{4}$ On Saturday nights in Western cities today, groups of young men, crazed on drugs and alcohol, attack, bash, knife, and sometimes kill innocent strangers. Pre-modern armies were notorious after successful battle, for their collective, intoxicated mania of rape and slaughter-a blood-lust for killing everybody they came across, whether children, women, or the elderly. Sometimes psychopathic violence is gratuitous, as in the case of Anita Cobby; sometimes it is rationalised, as in the case of rampaging armies - taking prize booty.

Tony Soprano is categorised by some of the psychoanalysts as a 'sociopath', a person who can inflict grievous harm with no bad conscience, but who is morally conscious of what he is doing. And indeed he is difficult to place. For long phases within the television series, the audience tends to quite like him. He is a strong family man. Much of the time he is an engaged father, loving his daughter, and doing a pretty good job

\footnotetext{
$\overline{{ }^{3} \text { Iliad, book 21 }}$, lines 34-127.

${ }^{4}$ The case is detailed in Julia Sheppard's book, Someone Else's Daughter, The Life and Death of Anita Cobby, Ironbark Press, Sydney, 1991.
} 
as father to a very difficult teenage son. He is attached to his wife, in spite of regular clandestine affairs; and he is warm to her whenever he sinks into a melancholy questioning of the meaning of life, which happens regularly. He has masculine virtue, as a fearless leader of the gang-quick-witted, insightful into the motives and intentions of others, a peerless capacity for strategic thinking, and for fast and decisive action. He has strong affection for the key gang members, although he can be ruthless if they are weak, or if they betray him.

Dr Melfi prefers not to know the extremes of what Tony does, turning the proverbial blind eye. And she comes to admire his manly power, finding that, after she has herself been attacked and raped, he is the one person she can trust, at least in fantasy, to protect and to avenge her. The men she knows - including her husband and the male analysts - now seem effete and ineffectual to her, and thereby contemptible. In the series, generally, men who are not part of the mob are shown as weak. They include Artie, a restaurant owner; a cousin of Tony who tries to go straight; and Tony's son, A. J., who is portrayed as a sissy with no stomach for men's business.

The audience finds itself sitting in the same chair as Dr Melfi-in its ambivalence towards Tony Soprano. The program puts the taunting proposition that what draws the onlooker to Tony has, as an essential part of it, his capacity for evil. His own defence is that he targets only members of the mob - and they all know the code they live by, and the consequences of betrayal. This is true as far as his most vicious acts are concerned; but innocent people are regularly intimidated and hurt by the mob, and he leads the mob.

A benign reading of Tony's appeal might posit that the full life requires living and acting in the world; such a life inevitably includes the winning and utilising of power; and it includes a need for adventure and risk. Modern middleclass life is out of balance: it is too secure; too well insured and protected from danger; too bureaucratised; in short, it is too genteel. Hence it sets up a craving for the opposite - in the imagination. Tony Soprano satisfies that craving.

The tougher reading is that viewers are titillated by the fear that many people - perhaps even they themselvesharbour a fragment of something similar to Soprano viciousness inside. The audience unwittingly identifies with Tony, who arouses deeply buried strains of sadism in it, universal ones. Viewers take pleasure, at an imaginative remove, in the powerful act of inflicting pain. Violence is violence, and it can be seductive.

The program engages with this discussion, by including a few psychopathic mobsters. They are contrasted with Tony. There is, for instance, Ralphie, who in a fit of rage bashes his own girlfriend to death, after she has insulted him in front of others, and questioned his manliness. Tony reacts by beating up Ralphie, out of disgust at the injustice, the unmanly killing of an innocent young woman, and by the conscienceless lack of control. Ralphie, who lacks any normal feelings of human warmth and attachment, is excited by sadistic cruelty.

An excessive fearfulness is common in modern Western upper-middle-class life. ${ }^{5}$ This is illustrated by the paranoia about children being abducted that impels parents to chauffeur them everywhere, including to school. The reality is that they live in suburbs in which crime rates are very low by any historical comparisons, and the statistical likelihood of child abduction is infinitesimal. Psychoanalytic literature suggests that paranoia is linked to unconscious fear of the same dark impulses in oneself, impulses which are then projected outwards onto the stigmatised other, or the imagined perpetrator of crime. ${ }^{6}$ As much as this is true, there is support for reading Dr Melfi and her colleagues in the The Sopranos as being agitated by a deeply suppressed Tony Soprano identification - which means identification with the clear-eyed expression of controlled violence.

To widen the perspective, the hypothesis that there may be a hidden demon lurking within is further illustrated in manic behaviour - times when otherwise normal persons are 'out of their minds', berserk with extreme emotion. In the Iliad, the most kind and gentle of men, Patroklos, in the heat of battle becomes carried away with blood-lust, to the point of cruelly mocking a dying Trojan whom he has just speared. The great builder of civilised cities, Alexander the Great, in a mania of raging grief after the death of his bosom friend, had the hapless and innocent doctor crucified who had been in attendance. In Euripides' Bacchae, the king's mother, in a trance induced by the god Dionysus, takes her son to be a lion, kills him, tears his body apart, and parades around with his head on a stake. Tony Soprano's acts of extreme violence usually occur when his temper boils over, pitching him momentarily out of control, red with rage. These border on Ralphie episodes, ones in which Tony is not much different from the psychopath. Soon after them, he collects himself.

There is a point at which the excuses stop. In the Anita Cobby case, a psychiatrist defended the ring-leader, John Travers, at his trial, on the grounds that he had had a terrible childhood; and, in the period before the attack he had been leading a half-crazed life, intoxicated on alcohol and marijuana, aggressive, paranoid, and very unstable. So what! A human community has been violated by what Travers dida kind of pollution has descended over it. It will not be able to settle, and return to some kind of normal living, until full retribution is carried out. In The Sopranos, one analyst tells

\footnotetext{
${ }^{5}$ E.g. Frank Furedi, Culture of Fear, Continuum, London, 2002.

${ }^{6}$ E.g. Erik Erikson, Childhood and Society, Penguin, London, 1965, ch. 9 .
} 
Carmella, Tony's wife, that he will not treat her unless she leaves her husband - for she is living off the proceeds of major crime, and he does not wish to be contaminated by blood-money.

\section{Violence and Courtesy}

Reflections on Violence is the title of a highly influential book published by Georges Sorel in 1906. Sorel advocated violence in politics to counter what he saw as the decadence of the times; but this was to be violence washed in the colours of mythic heroism, guided by a socialist moral code. For Sorel, violence could be ethical. ${ }^{7}$

To generalize, every human society depends on politics - the competent management of its public affairs. Politics pivots on power, and authority, which in part boil down to the capacity to mobilise effective violence, if necessary. Max Weber put a basic truth, if in exaggerated form, that the modern state "claims the monopoly of the legitimate use of physical force. 8

Politics is not the focus of my essay. And, whatever Georges Sorel's intentions, his book helped fuel, amongst early-twentieth-century cultural elites, a belief in therapeutic violence - a type of violence for the sake of violence that, it was hoped, would revitalise stagnant European societies. The ensuing historical reality of two world wars, Nazism, and Communism, put paid to any fantasy about the redemptive potentiality of collective violence.

In spite of Sorel and twentieth-century politics, the subject of my third thesis is a moral dimension linked with certain types of violence. Homer set the scene. The godlike, man-slaughtering warrior hero, Achilles, once the battles have finished, changes character. The last two books of the Iliad are dedicated to this change. In the first, Achilles organises funeral games. He does not compete himself, but provides prizes, adjudicates, settles petty disputes among the competing warriors, gives extra prizes to those who have come second, and one to the elderly Greek, Nestor, in recognition of his wise advice during the war. He does all this with generosity, good-will, and grace, establishing such a tone of courtesy that the other warriors come to behave better than their normal egocentric selves.

In the final book of the Iliad, Achilles welcomes the enemy king, Priam, into his dwelling-Priam has come to petition for the return of the corpse of his son, Hektor. Achilles addresses Priam, 'aged magnificent sir' and the

\footnotetext{
${ }^{7}$ Georges Sorel, Reflections on Violence, trans. T. E. Hulme \& J. Roth, Collier, New York, 1961.

${ }^{8}$ Max Weber, From Max Weber, ed. H. H. Gerth \& C. Wright Mills, Routledge \& Kegan Paul, London, 1948, p. 78. Also on this subject, Hannah Arendt, On Violence, Allen Lane, London, 1970.
}

two men settle down to drinking and feasting, weeping together about the futility and tragedy of the human condition.

Homer concludes his epic tragedy with a paradox: the most excessive brute on the field of battle has turned into the most courteous of gentlemen. This courtesy is not just some frivolous charm, but a redeeming quality of character that casts a serene calm over the last days of Achilles - the hero who is aware that he will die soon. The big man has been freed by suffering from normal human cares and ambitions, passions and pains, lifted above it all, a condition that is consummated in his final, intimate companionship with the enemy king, Priam.

I remember as a boy, and later as a young man, listening to Jack Dyer broadcasting Australian football games. In his earlier life as a player, Jack had been notorious for his tough, bruising play, leading his side with ruthless, courageous vigour-his nickname was 'Captain Blood'. As a radio commentator, Jack Dyer created a virtuoso story-telling style, in a deep nasal, gravelly voice, combining a Homeric flair for simile with two-minute sentences, in which the suspense was steadily built up, as clause piled on clause, with the subject of the sentence named only at the end-in the preceding crescendo of clauses it was an anonymous 'he'. Jack would intersperse talk of past moments and players, doing so with tender warmth and twinkling nostalgia, evoking for boys like me the sense of heroic past, and love for a mythic game that was bigger than the passing moment. Jack was a great educator. Above all, it was his character that was admirable: its enduringly memorable tone was one of benign courtesy.

In the television series Deadwood, the central character, Al Swearengen reprises Tony Soprano in combining a vicious capacity for violence with charismatic charm - in fact, he is the more charming of the two. His staff love and idolise him. This is because, in the Hobbesian state of nature that prevails in the town, he holds the community together, demonstrating brilliant and intuitive (and, at times, selfless) political leadership - talking out his strategy in wild but thoughtful monologues addressed to the head of a dead Indian chief he keeps in a box. The series implies that only a man with his ruthless, sometimes sadistic capacity for raw violence could hold his nerve and act decisively in a primal social world without law. Also, Swearengen's judgment of character is unerring, and he displays compassionate warmth for his staff, some of whom, like a severely handicapped woman, he employs out of charity. He exhibits a gruff, surly, ironic courtesy.

National myths are invariably tied to violent events, usually wars. In the Australian case, the source is the Great War and the Gallipoli campaign of 1915. For the soldiers who survived, bonds of blood-brotherhood mateship forged on the battle-field tended to be stronger 
than any experienced thereafter-bonds reaffirmed in later years on remembrance days, at reunions, and in retired servicemen's clubs. Post-war life itself often became shadowed, lived in a no-mans-land or purgatory, illuminated by the memories that mattered-nightmares too. ${ }^{9}$ Somehow, it was in the trenches under enemy gun fire that life was at the flood-tide, and everything else ephemeral, banal, and trivial. The Australian legend about Anzac centres on heroic mateship among the soldiers. ${ }^{10}$ Its tones mix the cheerful, the urbane, and the jocular with tender, tragic reminiscences. The whole is reflective of a higher courtesy.

$* * *$

Here is the paradox at the heart of civilised existence. This has been a men's story, one about extremes. It suggests that life is most real-full on, brilliant, no questions being asked - when lived in proximity to violence. Psychopathic violence warns about the forces unleashed in this domain. The awe, the silent unspeakable horror induced by what was done to Anita Cobby is the same as that witnessed at the climax of the crucifixion - in the generative heartland of Western culture. The onlooker is pitched outside normal time, and into a spectral zone radiated by an unearthly light - the darkness that descends at noon during the crucifixion. Full-on tragedy is catastrophe, which strikes from nowhere, without reason or sense, vast, cruel, remorseless, and final. Yet it serves as the gateway to the liberating of self from the cares of the world.

The civilised hope is that power may be sublimated. This occurs in the third of the American television series, Mad Men. Don Draper, the central character, is the one with male presence. His charisma is based on vocation, that he is excellent at his job, and that he is fearless, coolly insightful, and authoritatively decisive when necessary. He is not a violent man. But Don has no deep pleasures or attachments; he drifts through life wearing a false persona, which renders his sense of his own identity precarious, and his authenticity, in the viewer's eyes, compromised. He always withholds part of himself, which creates a sense of mystery around him - that mystery, in turn, compounds the power of his presence. $^{11}$

\footnotetext{
${ }^{9}$ The nightmare consequences for English soldiers damaged psychologically by the Great War are evoked by Pat Barker, in her novel Regeneration (1991).

${ }^{10}$ C. E. W. Bean, Official History of Australia in the War of 1914-18, Vol. I The Story of Anzac, Angus \& Robertson, Sydney, 1937, pp. 6057. Also, Bill Gammage, The Broken Years, Penguin, Melbourne, 1975, pp. $247-9$.

${ }^{11}$ I am excluding the fourth season of Mad Men (2010), which has problems of consistency, in character and narrative. In the first half of this fourth series, Don becomes unhinged, loses his mystery, and thereby his charm, and appears vulnerable and weak. At the end of the series he falls in love, finds attachment, and starts to take pleasure in his children.
}

Achilles was not at all like this. His big-man presence was unambiguous, as was his control over his role in events. Tony Soprano is similar to Don Draper rather than to Achilles: in his case, precariously balanced between experiencing himself, on the one hand, as a large, powerful man whom everyone fears and, on the other, as utterly empty and lost. The implication is that identity, post-Hamlet, is a modern issue, unrelated to the explicit theme of violence.

The three theses on violence establish a vector pointing in one direction, towards courtesy. Arguably, courtesy is the strongest of male virtues, even the core one.

Courtesy became a prime virtue in the Renaissance, its form the ethos of the courtier. The ideal character type of the courtier was most famously spelled out by Castiglione, in The Book of the Courtier (1528). Hundreds of books of manners followed, in England led by Thomas Elyot's The Book named the Governor (1531), books that codified the education and conduct that made a gentleman. This was a literature generated by status anxiety, with its focus on external show - not my concern here. It was, nevertheless, indicative of a post-mediaeval struggle to define the ideal male character, a struggle that orbited around notions of courtesy.

What may we conclude about courtesy? With Achilles and Jack Dyer it rises as the fulfilment of the male drive- they have achieved all they needed in the domain of power. As a result, they do not suffer from any frustration of ambition, or restlessness to do more. There are no mountains that interest them left to climb. Consequently, they are completely secure, and at ease in how they have lived, and who they are. They may regret some of the things they did, and even profoundly so, but their remorse is transformed into a resigned shrug of the shoulders, as if to signal that is the way things were, and there's nothing to be done about that. Freedom from insecurity brings a mellow and selfless kind of fearlessness.

Courtesy is a type of benevolence, with its source in fullness of character, which spills over, engaging those in the vicinity. It is encapsulated in Achilles' address to Priam: 'Aged, magnificent sir!' There is friendly, tender respect here, warm generosity, and towards a man who is the enemy. This is fellowship, a blessed conviviality between two men who have both suffered obliterating grief. It sets up a space within which the men may converse about the deep questions. Courtesy is gracious good humour; it does not judge; it is unselfish; it influences by example; and it is kind. Courtesy is the flower that grows from a plant with its roots in violent power.

John Carroll is Professor of Sociology at La Trobe University in Melbourne, Australia. He is author most recently of Ego and Soul: The Modern West in Search of Meaning (Counterpoint, 2010). 